\title{
原著論文
}

\section{身長による持続硬膜外鎮痛時のフェンタニル 至適投与量の検討}

\author{
山岸昭夫*1 朝井裕一*1 岩崎 寬*2
}

[要旨］開胸手術患者 60 名を対象とし，0.2\%ロピバカインとフェンタニルの併用 による持続硬膜外鎮痛を行った．身長 $155 \mathrm{~cm}$ 以上には $6 \mathrm{ml} / \mathrm{h}$ ，身長 $155 \mathrm{~cm}$ 未満 には $4 \mathrm{ml} / \mathrm{h}$ で投与し, フェンタニルの投与量を $10 \mu \mathrm{g} / \mathrm{h}, 15 \mu \mathrm{g} / \mathrm{h}$ と変化させた. 身長と術後 6 時間後のVAS(visual analogue scale)に相関関係が認められ，身長 が高いほど局所麻酔薬に併用するフェンタニルを多く必要とすることが示唆された. また, 患者の体重当たりの投与量が増加すると嘔気を訴える割合が増えたことから, 身長だけではなく体重も考慮する必要がある.

キーワード : 硬膜外鎮痛, フェンタニル, 身長

(日臨麻会誌Vol.28 No.2, 319～324, 2008)

\section{はじめに}

術後の持続硬膜外鎮痛薬として，局所麻酔薬とつ エンタニルの併用は一般的であり，その有用性も数 多く報告されている ${ }^{1), 2)}$. 硬膜外鎮痛に使用する局 所麻酔薬の効果は身長によって影響を受けるが3), 局所麻酔薬に併用するフェンタニルの投与量も同様 に身長によって影響を受ける可能性がある。そこで 今回，身長により局所麻酔薬に併用するフェンタニ ルの投与量を変化させ，その鎮痛効果と副作用につ いて検討した。

\section{I 対象と方法}

2005 年 6 月から 2006 年 6 月までに $10 \mathrm{~cm}$ 以上の皮 切に及ぶ開胸手術を予定されたASA 術前評価分類 1 ・ 2 の患者 60 名を対象とした。本研究を実施する にあたつて当施設の倫理委員会の承認を得，患者に は術前に本研究内容を説明し，文書にて同意を得た。
麻酔前投薬としてジアゼパム $5 \mathrm{mg}$, ファモチジン $20 \mathrm{mg}$ を手術室入室 2 時間前に内服させ，手術室入 室後, 硬膜外カテーテルを左側臥位で T5〜 T8 の椎 間から挿入し，頭側に $5 \sim 8 \mathrm{~cm}$ 留置した。麻酔導入

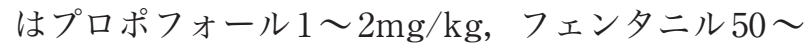
$100 \mu \mathrm{g}$, ベクロニウム $0.1 \mathrm{mg} / \mathrm{kg}$ にて行い, 麻酔維 持は動脈血酸素分圧 $\left(\mathrm{PaO}_{2}\right) 100 \mathrm{mmHg}$ 以上を保つよ うに吸入酸素濃度を調節し，プロポフォール 2 〜 $6 \mathrm{mg} / \mathrm{kg} / \mathrm{h}$ の持続投与で行った。術中硬膜外鎮痛と して硬膜外腔より $1 \%$ リドカインを 6 〜 $10 \mathrm{~m} l / \mathrm{h}$ で持 続投与した。手術終了 1 時間前に $1 \%$ リドカインの 投与を中止し，ロピバカイン $(\mathrm{R})$ とフェンタニル $(\mathrm{F})$ を併用した持続硬膜外鎮痛を開始し，術後 48 時間 継続した。患者を身長と併用するフェンタニル $(\mathrm{F})$ の投与量により以下の 4 群に分類した。 L1 群〈身長 $155 \mathrm{~cm}$ 未満 $\rangle: 0.2 \% \mathrm{R} 190 \mathrm{~m} l+\mathrm{F} 10 \mathrm{~m} l(4 \mathrm{~m} l / \mathrm{h}, \mathrm{F}$ $10 \mu \mathrm{g} / \mathrm{h}), \mathrm{L} 2$ 群〈身長 $155 \mathrm{~cm}$ 未満〉: $0.2 \% \mathrm{R}$ $185 \mathrm{~m} l+\mathrm{F} 15 \mathrm{~m} l(4 \mathrm{~m} l / \mathrm{h}, \quad \mathrm{F} 15 \mu \mathrm{g} / \mathrm{h}), \mathrm{H} 1$ 群〈身長
*1独立行政法人国立病院機構帯広病院麻酔科

*2旭川医科大学麻酔・蘇生学講座
受理日 2007. 2. 9. 採択日 2007. 11.29.
著者連絡先 山岸昭夫

㝵 078-8510 旭川市緑が丘東 2条1-1-1 旭川医科大学麻酔・蘇生学講座 


\begin{tabular}{cc} 
表1 & \\
\hline Bromage scale & \multicolumn{1}{c}{ 判断基準 } \\
\hline scale 0 & 膝や足を十分に曲げることができる \\
scale 1 & 足を伸ばしたまま挙げることができない \\
scale 2 & 膝を曲げることができない \\
scale 3 & 足首を曲げることができない \\
\hline
\end{tabular}

\section{表2 患者背景}

\begin{tabular}{ccccc}
\hline & $\mathrm{L} 1$ 群 & $\mathrm{L} 2$ 群 & $\mathrm{H} 1$ 群 & $\mathrm{H} 2$ 群 \\
\hline 症例数 (例) & 15 & 15 & 15 & 15 \\
年齢 $($ 歳) & $64.3 \pm 11.4$ & $67.5 \pm 4.3$ & $61.6 \pm 9.3$ & $60.8 \pm 9.2$ \\
身長 $(\mathrm{cm})$ & $148.5 \pm 4.6$ & $150.1 \pm 4.0$ & $163.4 \pm 5.8$ & $167.2 \pm 6.8$ \\
体重 $(\mathrm{kg})$ & $54.3 \pm 9.0$ & $54.6 \pm 7.7$ & $61.3 \pm 9.2^{*}$ & $60.5 \pm 7.9^{*}$ \\
手術時間 (分) & $184 \pm 107$ & $199 \pm 94$ & $184 \pm 87$ & $193 \pm 101$ \\
\hline (平均䛧士標淮倨差 & & & &
\end{tabular}

(平均值士標準偏差)

* : L1, L2 群と比較して有意差あり $(P=0.0131<0.05)$

$155 \mathrm{~cm}$ 以上 $\rangle: 0.2 \% \mathrm{R} 290 \mathrm{~m} l+\mathrm{F} 10 \mathrm{~m} l(6 \mathrm{~m} l / \mathrm{h}, \quad \mathrm{F}$ $10 \mu \mathrm{g} / \mathrm{h}), \mathrm{H} 2$ 群〈身長 $155 \mathrm{~cm}$ 以上〉: $0.2 \% \mathrm{R}$ $285 \mathrm{~m} l+\mathrm{F} 15 \mathrm{~m} l(6 \mathrm{~m} l / \mathrm{h}, \mathrm{F} 15 \mu \mathrm{g} / \mathrm{h})$. 術後患者が 痛みを訴えた場合にはジクロフェナクナトリウム 25 〜 50mg を直腸内投与し, 鎮痛効果が不十分な場合 にはブプレノルフィン $0.2 \mathrm{mg}$ を筋肉内投与した.

評価項目は術後 $1 ， 3 ， 6 ， 12 ， 24 ， 48$ 時間後の visual analogue scale (VAS), 術後 3 時間後の冷覚 遮断域, 術後 48 時間の追加鎮痛薬使用回数, 下肢 運動機能の程度(Bromage scale：表1)を記録した。 また嘔気，尿閉，皮膚掻痒感，呼吸抑制の有無につ いても調査した。

結果は平均值士標準偏差で表した。統計処理は Kruskal-Wallis検定を行い, 有意差があった場合に はScheffe検定を用いた。 $P<0.05$ を有意とした。身 長とVASの関係については回帰分析を用い， $P<$ 0.05 を有意差ありとした。

\section{II 結 果}

L1，L2，H1，H2 群それぞれ 15 症例，計 60 例の
開胸手術症例に対し術後持続硬膜外鎮痛を行った。 患者背景因子において，体重で身長 $155 \mathrm{~cm}$ 未満の群 と $155 \mathrm{~cm}$ 以上の群とで有意差を認めた。それ以外の 因子には有意差を認めなかった(表2).

術後 3 時間後の冷覚遮断域は L1，L2，H1，H2 群 それぞれ $7.8 \pm 0.8,7.9 \pm 0.7,7.9 \pm 0.9,7.9 \pm 0.7$ 分 節であり，有意差を認めなかった。

術後VASの推移を図1に示す。VASは $3,6,12$ 時間後で H1 群が他の 3 群に比較して有意に高かっ た。その他のVASにおいては有意差を認めなかっ た。フェンタニル投与量 $10 \mu \mathrm{g} / \mathrm{h}$ の群( $\mathrm{L} 1, \mathrm{H} 1$ 群) で は身長と術後 6 時間後のVASに相関関係が認められ た(図2).

術後 48 時間の鎮痛薬使用人数は L1, L2, H1，H2 群それぞれ9名(60\%)，7名(47\%)，8名(53\%)，8 名 $(53 \%)$ と有意差を認めなかったが, 平均使用回数 はL1，L2，H1，H2群それぞれ $0.73 \pm 0.77 ， 0.66 \pm$

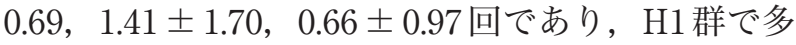
い傾向であった $(P=0.624>0.05)$.

副作用は嘔気がL1，L2，H1，H2群それぞれ1名 


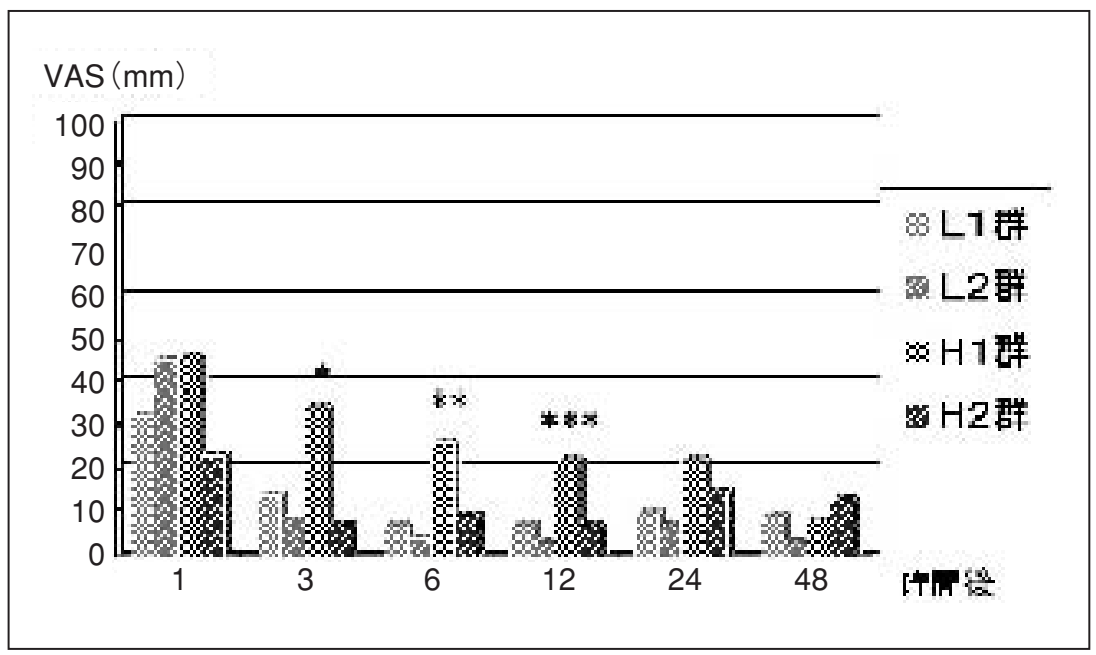

図1 VASの推移

* : H1 群において他の群より有意に高值 $(P=0.0049<0.01)$

** : H1 群において他の群より有意に高值 $(P=0.0182<0.05)$

*** : H1 群において他の群より有意に高值 $(P=0.0029<0.01)$

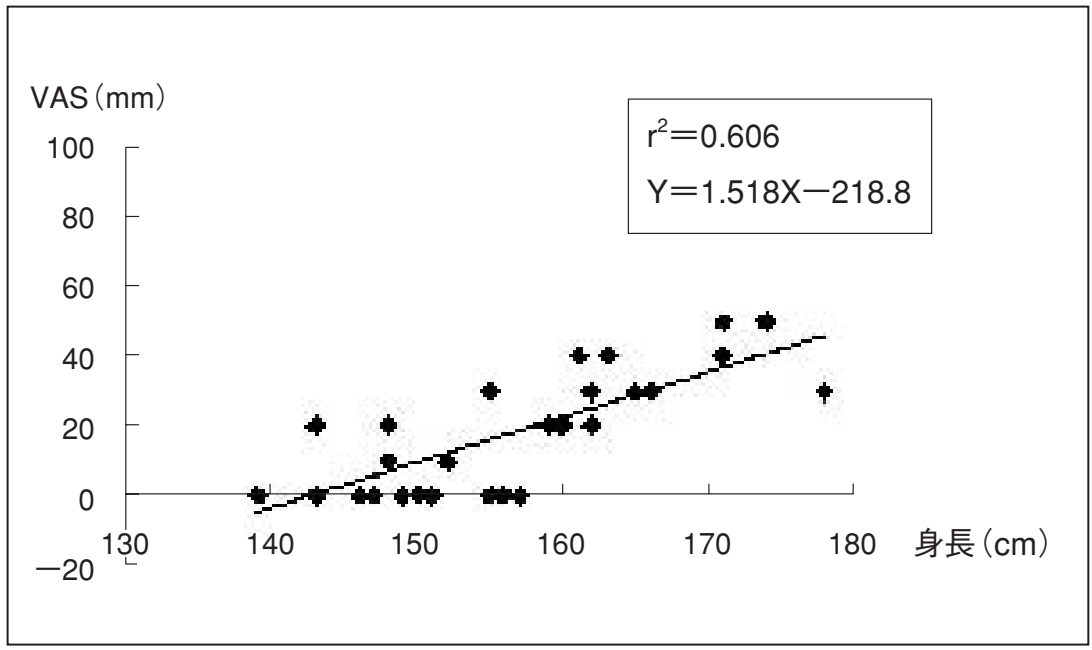

図2 身長と術後6 時間後VASの関係

$(7 \%) ， 6$ 名 $(40 \%) ， 1$ 名 $(7 \%), 0$ 名 $(0 \%)$ と 2 群 で有意に多かった(表3)。L2群で嘔気を訴えた患者 の平均体重は $48.3 \pm 4.5 \mathrm{~kg}$ と他の群より有意に低く, フェンタニル投与量も $0.31 \mu \mathrm{g} / \mathrm{kg} / \mathrm{h}$ と他の群より有 意に高かった(表4)。その他の副作用には有意差を 認めなかった(表3).

筋力低下はどの群でも認められず, Bromage scaleは経過中すべて0であった。

\section{III 考 察}

持続硬膜外鎮痛は強力な鎮痛効果を発揮し, 術後 鎮痛に広く使用されている。硬膜外鎮痛における効 果は, 硬膜外カテーテルの挿入部位や患者の年齢, 身長などで左右される ${ }^{3) \sim 5)}$ ，また，使用する局所麻 酔薬の種類や容量, オピオイドの添加の有無などで も鎮痛効果は異なり, 症例ごとに調節する必要が 
表 3 副作用

\begin{tabular}{lcccc}
\hline & $\mathrm{L} 1$ 群 & $\mathrm{L} 2$ 群 & $\mathrm{H}$ 1 群 & $\mathrm{H}$ 2 群 \\
\hline 副作用 & & & & \\
嘔気 (例) & 1 & $6^{*}$ & 1 & 0 \\
尿閉 (例) & 0 & 2 & 2 & 1 \\
皮膚掻痒感 (例) & 1 & 2 & 2 & 0 \\
呼吸抑制 (例) & 0 & 0 & 0 & 0 \\
\hline * : 他群より有意に増加 $(P=0.0069<0.01)$ & & &
\end{tabular}

表4 体重当たりの平均フェンタニル投与量

\begin{tabular}{lcc}
\hline & 体重 $(\mathrm{kg})$ & $\begin{array}{c}\text { フェンタール投与量 } \\
(\mu \mathrm{g} / \mathrm{kg} / \mathrm{h})\end{array}$ \\
\hline L1 群 & $54.3 \pm 9.0$ & $0.18 \pm 0.02$ \\
L2 群 & & \\
$\quad$ 嘔気患者6名 & $48.3 \pm 4.5^{*}$ & $0.31 \pm 0.04^{* *}$ \\
$\quad$ その他9名 & $57.7 \pm 5.8$ & $0.26 \pm 0.03$ \\
$\mathrm{H} 1$ 群 & $61.3 \pm 9.2$ & $0.16 \pm 0.02$ \\
$\mathrm{H} 2$ 群 & $60.5 \pm 7.9$ & $0.25 \pm 0.04$ \\
\hline (平均值士標準偏差 $)$ & \\
$*$ : 他の群より有意に低值 $(P=0.0121<0.05)$ & \\
$* *:$ 他の群より有意に高值 $(P=0.0124<0.05)$ &
\end{tabular}

ある。

ロピバカインによる術後持続硬膜外鎮痛は, ブピ バカインに比して心毒性が低いことや低濃度におい て運動神経遮断作用が弱いことから，広く使用され ている．持続投与の速度についてはTurner ら ${ }^{6)} は$ $0.2 \%$ ロピバカインの $6 \sim 14 \mathrm{~m} l / \mathrm{h}$ の硬膜外投与が有 用であると報告している。しかし，日本人において は $0.2 \%$ ロピバカインの投与量が $8 \mathrm{~m} l / \mathrm{h}$ 以上では血 圧が低下する可能性があり, $6 \mathrm{~m} l / \mathrm{h}$ 以下の硬膜外投 与が安全に施行可能であると報告されている77,8). また， $4 \mathrm{ml} / \mathrm{h}$ の投与は身長 $155 \mathrm{~cm}$ 以上の症例では鎮 痛効果が不十分であり, $155 \mathrm{~cm}$ 未満の患者の夕に有 効であると報告されている ${ }^{8)}$.したがって，今回の 研究では $0.2 \%$ ロピバカインの持続投与量を身長 $155 \mathrm{~cm}$ 以上の症例では $6 \mathrm{ml} / \mathrm{h}$, 身長 $155 \mathrm{~cm}$ 未満の症 例では $4 \mathrm{ml} / \mathrm{h}$ とした。
$0.2 \%$ ロ ピバカインに併用するフェンタニルの持 続硬膜外投与量は， $5 \sim 15 \mu \mathrm{g} / \mathrm{h}$ で大きな副作用もな く良好な術後鎮痛が得られたと報告されている ${ }^{2), 9)}$. しかし，投与量が少ない場合には鎮痛効果が不十分 であると考えられ，今回の研究ではフェンタニルの 持続硬膜外投与量を $10 \mu \mathrm{g} / \mathrm{h} と 15 \mu \mathrm{g} / \mathrm{h}$ の 2 種類で 行った。

硬膜外麻酔における局所麻酔薬の効果は身長によ つて影響を受けるといわれ，身長が高いほど 1 脊髄 分節当たりの必要量が多く ${ }^{3)}$, 痛覚遮断域を維持し づらい ${ }^{10)}$. 一方，局所麻酔薬に併用するフェンタニ ルの投与量も同様に身長によって影響を受ける可能 性がある。今回の結果から，VAS と身長との間に 相関関係が認められ，身長が高いほど局所麻酔薬に 併用するフェンタニルを多く必要とすることが示唆 された。 $0.2 \%$ ロピバカインに併用するフェンタニ 
ル投与量は身長 $155 \mathrm{~cm}$ 以上の場合, $10 \mu \mathrm{g} / \mathrm{h}$ では

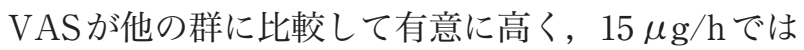
良好な鎮痛効果を示したことから，15 $\mu \mathrm{g} / \mathrm{h}$ が適切 であることが考えられた。しかし, 身長 $155 \mathrm{~cm}$ 未満 の場合はフェンタニル投与量が $10 \mu \mathrm{g} / \mathrm{h} と 15 \mu \mathrm{g} / \mathrm{h}$ でVASに有意差を認めず，両群において良好な鎮 痛効果を示したことより，10 $\mu \mathrm{g} / \mathrm{h}$ で十分であると 考えられた。

また，嘔気を訴えた患者は小柄な患者が多く，体 重当たりの平均フェンタニル投与量を測定したとこ ろ $0.31 \mu \mathrm{g} / \mathrm{kg} / \mathrm{h}$ であった。これは，同じ群の嘔気を 訴えなかった患者の体重当たりのフェンタニル投与 量が $0.26 \mu \mathrm{g} / \mathrm{kg} / \mathrm{h}$ であったのに比べ有意に高かっ た. 術後鎮痛としてフェンタニル持続静脈内投与に て管理する際には主に体重を考慮することから ${ }^{11)}$, 硬膜外腔からフェンタニルを持続投与する際にも身 長に加え，体重も考慮すべき必要があると考えら れた。

開胸手術の術後においては, 胸腔ドレーンをしば らく留置しなければならず，排痰時や体動時の痛み を抑えるために適切な術後鎮痛が必要である。今回 の研究より，身長が高いほど局所麻酔薬に併用する フェンタニルを多く必要とすることが示唆された。 持続硬膜外鎮痛を行う際には，個々の患者の体型を 考慮し，局所麻酔薬やフェンタニルの投与量を調節 しなくてはならない.

\section{参考文献}

1) Macias $\mathrm{A}$, Monedero $\mathrm{P}$, Adame $\mathrm{M}$, et al. : A randomized, double-blinded comparison of thoracic epidural ropivacaine, ropivacaine/fentanyl, or bupivacaine/fentanyl for postthoracotomy analgesia. Anesth Analg 95 : 1344-1350, 2002

2）鈴木麻葉，大澤了, 金井昭文ほか：ロピバカインとフェ ンタニルを用いたPCEA付き術後持続胸部硬膜外鎮痛に おける鎮痛効果の検討。麻醉 $54: 2-7,2005$

3) Bromage PR : Spread of analgesic solutions in the epidural space and their site of action : a statistical study. Br J Anaesth $34: 161-178,1962$

4) Bromage PR : Mechanism of action of extradural analgesia. Br J Anaesth 47 : 199-211, 1975

5) Bromage PR : Ageing and epidural dose requirements : segmental spread and predictability of epidural analgesia in youth and extreme age. Br J Anaesth 41 : 1016-1022, 1969

6) Turner G, Blake D, Buckland M, et al. : Continuous extradural infusion of ropivacaine for prevention of postoperative pain after major orthopaedic surgery. $\mathrm{Br} \mathrm{J}$ Anaesth 76 : 606-610, 1996

7）冨永昌宗, 高橋成輔, 奥田佳朗ほか：長時間作用性局所 麻酔薬塩酸ロピバカイン $(\mathrm{NA}-001)$ の術後鎮痛効果の検討 一第 III相試験一。臨床医薬 $15 ： 1253-1272 ， 1999$

8）大澤正己，鈴木太，吉矢生人ほか：長時間作用性局所麻 酔薬塩酸ロピバカイン $(\mathrm{NA}-001)$ の術後鎮痛効果と安全性 に対する注入速度の検討一第 II 相試験一. 臨床医薬 15 ： 1117-1135，1999

9）金井昭文，木下伸，鈴木麻葉ほか：整形外科下肢手術を 対象とした術後腰部硬膜外鎮痛に扔けるロピバカインの 有効性の検討. 麻酔 54：8-13，2005

10）金井昭文, 中原絵里, 小坂康晴ほか：術後持続腰部硬膜 外鎮痛におけるロピバカインとブピバカインの比較. 麻 酔 $52 ： 832-839$, 2003

11）明石学, 柴田康之, 洪淳憲ほか：フェンタニル持続静脈 内投与による術後鎮痛。日臨麻会誌 $23 ： 218-226,2003$ 


\title{
Optimal Dose of Fentanyl in Continuous Epidural Infusion According to the Patient's Height after Thoracic Surgery
}

\author{
Akio YAMAGISHI*1, Yuichi ASAI*1, Hiroshi IWASAKI*2 \\ ${ }^{* 1}$ Department of Anesthesiology, Obihiro National Hospital \\ *2Department of Anesthesiology and Critical Care Medicine, Asahikawa Medical College
}

\begin{abstract}
We investigated the analgesic effect and side effects of continuous epidural infusion of fentanyl after thoracic surgery. Sixty patients were included in this study. Patients were randomly allocated to four groups. Patients less than $155 \mathrm{~cm}$ in height were divided into group L1 $(2.5 \mu \mathrm{g} / \mathrm{m} l$ fentanyl $)$ and group L2 $(3.75 \mu \mathrm{g} / \mathrm{ml}$ fentanyl $)$, and patients more than $155 \mathrm{~cm}$ in height were divided into group $\mathrm{H} 1(1.66 \mu \mathrm{g} / \mathrm{m} l$ fentanyl $)$ and group $\mathrm{H} 2(2.5 \mu \mathrm{g} / \mathrm{m} l$ fentanyl $)$. Epidural infusion was $4 \mathrm{~m} l / \mathrm{h}$ in patients less than $155 \mathrm{~cm}$ in height and $6 \mathrm{ml} / \mathrm{h}$ in patients more than $155 \mathrm{~cm}$ in height. Pain scores (visual analogue scale : VAS) were assessed at 1, 3, 6, 12, 24 and 48 hrs after surgery. Degrees of satisfaction regarding pain relief and complications during a period of $48 \mathrm{hrs}$ after surgery were compared. Pain scores in the group H1 were significantly higher than those in the other groups at 3, 6 and $12 \mathrm{hrs}$ after surgery. There was more postoperative nausea and vomiting in the group L2 than in the other groups. The average weight in the group L2 was significantly lighter than those in the other groups. In conclusion, weight must be taken into consideration when using continuous epidural infusion of $0.2 \%$ ropivacaine with fentanyl.
\end{abstract}

Key Words : Epidural infusion, Fentanyl, Height

The Journal of Japan Society for Clinical Anesthesia Vol.28 No.2, 2008 